УдК 616.33/.34-005.1-036.87-02: [ 616.136.41+616.342]-007.64.

DOI 10.11603/2414-4533.2017.3.8164

СЛ. С. БІЛЯНСЬКИЙ, М. С. СЛУШИНСЬКИЙ, А. Д. КАЛЬЧЕНКО

Національний медичний університет імені О. О. Богомольця

\title{
Рецидивуюча хронічна шлунково-кишкова кровотеча, зумов.лена псевдоаневризмою власної печінкової артерї та псевдодивертикулом цибулини дванадцятипалої кишки
}

\begin{abstract}
У статті представлено клінічний випадок хірургічного лікування псевдоаневризми власної печінкової артерії, псевдодивертикулу дванадцятипалої кишки з рецидивуючою хронічною кровотечею. Хворому з рецидивуючою хронічною кровотечею протягом 2 років виконано КТ ОЧП з внутрішньовенним контрастуванням, 3D моделювання гілок truncus coeliacus, за результатами якого у пацієнта виявлено КТ-ознаки аневризми а.hepatica properia. Прийнято рішення про проведення верхньосерединної лапаротомії, інтраопераційно виявлено аневризму а. hераtica propria, від верхівки псевдоаневризми - відходження стовбура a. gastrica dextra $з$ гілкою до псевдодивертикулу дванадцятипалої кишки. A. gastrica dextra перев’язана і пересічена. Псевдодивертикул дванадцятипалої кишки інвагінований в просвіт цибулини дванадцятипалої кишки серозно-м’язовими швами. Протягом 19 місяців післяопераційного спостереження рецидиву кровотечі не виявлено.
\end{abstract}

Ключові слова: хронічна рецидивуюча шлунково-кишкова кровотеча; псевдодивертикул дванадцятипалої кишки; псевдоаневризма а.hepatica propria.

Кровотечі з верхніх відділів шлунково-кишкового тракту (ШКТ) частою $є$ причиною екстреної госпіталізації та потенційно небезпечним для життя станом. Захворюваність сягає 40-150 випадків на 100000 госпіталізацій в рік, а смертність внаслідок кровотечі з верхніх відділів ШКТ у всьому світі коливається від 0,9 до 26,5 \%, залежно від рівня медичного забезпечення в тій чи іншій країні [1]. Незважаючи на те, що кровотеча $є$ поширеним симптомом, причини шлунково-кишкової кровотечі істотно різняться. Кровотеча з верхніх відділів ШКТ може бути наслідком ерозивно-виразкових уражень стравоходу, шлунка, онкологічних захворювань, патологічних процесів сусідніх органів та систем. Визначення причини кровотечі, встановлення вірного діагнозу є запорукою вибору методів лікування [2]. Кровотечі з верхніх відділів щлунково-кишкового найчастіше зумовлені виразкою шлунка або дванадцятипалої кишки, які складають 20 - $67 \%$, ерозивний гастрит або дуоденіт - 4 - $31 \%$, варикозно розширені вени стравоходу в $4-20 \%$ випадків, ерозивний езофагіт - 3 - $12 \%$, новоутворення верхніх відділів ШКТ (поліпи, пухлини) - 2 - 8 \%, синдром МеллоріВейса - 4-12\%, синдром Дьєлафуа-1 - 5,8 \%. Менш поширеними причинами кровотечі в 3 19 \% є портальна гіпертензивна гастропатія, ангіодисплазія, судинні ектазії антрального відділу шлунка, гемофілія, ураження Камерона, ектопічні судини $[3,4,5]$.

Найбільш достовірним діагностичним та лікувальним методом $є$ фіброгастроскопія, ендоскопічна зупинка кровотечі. Однак у клінічній прак- тиці трапляються випадки, коли джерело кровотечі неможливо ідентифікувати під час ендоскопії [6]. Зазвичай, саме рідкісні причини шлунковокишкової кровотечі потрапляють до цієї категорії, спонукаючи клініцистів до пошуку причини, використовування додаткових методів діагностики, покладаючись на свій досвід.

Ми презентуємо клінічний випадок псевдоаневризми власної печінкової артерії, псевдодивертикулу дванадцятипалої кишки з рецидивуючою хронічною кровотечею.

Клінічний випадок. Хворий М., 53 р., госпіталізований у відділення хірургії КМКЛ № 18 зі скаргами на дьогтеподібні випорожнення, загальну слабість. 3 анамнезу відомо, що у 2013 р. у хворого діагностовано кровотечу з виразки дванадцятипалої кишки та проведено ендоскопічний гемостаз. Унаслідок неефективності лікування та маніфестації кровотечі виконано операційне лікування в обсязі дуоденотомії з висіченням виразки передньої стінки дванадцятипалої кишки, дуоденопластики. Через місяць після перенесеного операційного втручання хворого госпіталізовано повторно з приводу рецидиву кровотечі, проведено ендоскопічний гемостаз. Враховуючи ризик рецидиву кровотечі та анамнестичні дані, виконана ендоваскулярна целіако-мезентерікографія 3 натупною емболізацією a.gastroduodenalis. Протягом наступних 2 років хворого неодноразово госпіталізовували з клінічними ознаками кровотечі з виразки дванадцятипалої кишки в хірургічні стаціонари міста Києва, про що свідчили надані виписки, однак при обстеженні джерело 


\section{ПОВІДОМЛЕННЯ}

кровотечі не було встановлено при жодній госпіталізації.

Під час чергової госпіталізації хворого було обстежено в умовах хірургічного відділення Київської міської клінічної лікарні № 18. При проведенні ЕГДС верифіковано рубцеву деформацію та дві зарубцьовані виразки дванадцятипалої кишки по передній стінці. Поблизу післяопераційного рубця виявлено невелику судину 3 цівкою кровотечі. Виконано ендоскопічний гемостаз - кліпування судини. За час спостереження в стаціонарі після проведення ендоскопічного гемостазу ознак рецидиву кровотечі не виявляли, однак, враховуючи анамнез, загрозу повторних кровотеч та дані ЕГДС, хворого обстежено повторно. Виконано КТ ОЧП з внутрішньовенним контрастуванням, 3D моделювання гілок truncus coeliacus, за результатами якого у пацієнта виявлено КTознаки аневризми а. hepatica propria.

Прийнято рішення про проведення операційного лікування. Виконана верхньосерединна лапаротомія. Виділено всі елементи lig. hepatoduodenalis. Під час ревізії елементів зв'язки виявлено дилатацію а. hepatica propria на всьому протязі, з псевдоаневризмою в ділянці розгалуження артерії на праву і ліву печінкові гілки. Виділено a.gastroduodenalis, в просвіті якої виявлено емболи, при огляді встановлено, що устя артерії не емболізоване. Артерія

\section{СПИСОК ЛІТЕРАТУРИ}

1. Shah H. Endoscopic parameters of upper GI bleedings / H. Shah // International Journal of Community Health and Medical Research. - 2016. - Vol.2, Issue 1.

2. Wei Zhang. Unusual causes of upper gastrointestinal bleeding: Review of Chinese literature / Wei Zhang, Eliakim Manda, Ming Qiu // Intractable Rare Dis. Res. - 2012. - Vol. 1 (1). - P. 18-22. 3. Thomas Tielleman. Epidemiology and risk factors for upper gastrointestinal bleeding / Thomas Tielleman, Daniel Bujanda, Byron Cryer // Gastrointest. Endoscopy Clin. N. Am. - 2015. Vol. 25. - P. 415-428,

\section{REFERENCES}

1. Shah, H. (2016). Endoscopic parameters of upper GI bleedings. International Journal of Community Health and Medical Research, 2 (1).

2. Wei Zhang, Eliakim Manda, Ming Qiu, \& Wei Zhang (2012). Unusual causes of upper gastrointestinal bleeding: Review of Chinese literature. Intractable Rare Dis. Res., 1 (1), 18-22.

3. Thomas Tielleman, Daniel Bujanda, \& Byron Cryer (2015). Epidemiology and risk factors for upper gastrointestinal bleeding. Gastrointest. Endoscopy Clin. N. Am., 25, 415-428. перев’язана і пересічена. Від верхівки псевдоаневризми відходження стовбура а. gastrica dextra, гілки якої підходили до верхньо-задньої стінки цибулини дванадцятипалої кишки. Остання деформована, на її верхньо-задній стінці виявлено псевдодивертикул, до якого підходила а. gastrica dextra, яка і була джерелом кровопостачання останнього. Артерія перев’язана і пересічена. Псевдодивертикул дванадцятипалої кишки інвагінований в просвіт цибулини дванадцятипалої кишки серозно-м’язовими швами. Перебіг післяопераційного періоду не ускладнений. Хворого виписали зі стаціонару на 9-ту післяопераційну добу. Протягом 19 місяців спостереження рецидиву кровотечі не виявлено.

Висновки. 1. Більшість випадків кровотечі 3 верхніх відділів ШКТ виникає внаслідок виразкової хвороби шлунка та дванадцятипалої кишки (20-67 \% ), інші причини кровотечі є більш рідкісними, в тому числі судинні аномалії.

Не всі причини кровотечі з верхніх відділів ШКТ можуть бути візуалізовані за допомогою рутинних методів діагностики, враховуючи ендоскопічне дослідження.

При наявності кровотечі з верхніх відділів ШКТ без можливості візуалізувати його джерело за допомогою ендоскопії, доцільним є застосування інших методів діагностики, як КТ та ангіографія з 3D моделюванням магістральних судин.

4. Unusual causes of upper gastrointestinal bleeding / Keyur Parikh, Meer Akbar Ali, C. K. Richard, M. D. Wong // Gastrointest. Endoscopy Clin. N. Am.

5. Don Rockey C. Causes of upper gastrointestinal bleeding in adults / Don C. Rockey, Mark Feldman, Anne C. Travis // AGAF. - 2016. - Vol. 12.

6. Usefulness of the forrest classification to predict artificial ulcer rebleeding during second-look endoscopy after endoscopic submucosal dissection / Duk Su Kim, Yunho Jung, Ho Sung Rhee [et al.] // Clin. Endosc. - 2016. - Vol. 49 (3). - P. 273-281.

4. Keyur Parikh, Meer Akbar Ali, Richard, C.K., \& Wong, M.D. Unusual causes of upper gastrointestinal bleeding. Gastrointest. Endoscopy Clin. N. Am.

5. Don Rockey C., Mark Feldman, Anne C. Travis (2016). Causes of upper gastrointestinal bleeding in adults. AGAF, 12.

6. Duk Su Kim, Yunho Jung, Ho Sung Rhee, (2016). Usefulness of the forrest classification to predict artificial ulcer rebleeding during second-look endoscopy after endoscopic submucosal dissection. Clin. Endosc., 49 (3), 273-281. 
O. Bohomolets National Medical University

\title{
RECURRENT CHRONIC GASTROINTESTINAL BLEEDING, CONDITIONED BY PSEUDOANEURYSM OF PROPER HEPATIC ARTERY AND PSEUDO-DIVERTICULUM OF DUODENUM
}

The clinical case of surgical treatment of pseudoaneurysm of a.hepatica propria, duodenal pseudodiverticul with relapsing chronic bleeding is presented. A patient with relapsing chronic bleeding for 2 years has been performed CT with intravenous contrast, 3-D simulation of the branches of truncus coeliacus, which resulted in the CT-signs of pseudoaneurysm a.hepatica propria. It was decided to carry out upper-middle laparotomy, intraoperatively detected pseudoaneurysm a.hepatica propria, from the top of the pseudoaneurysm, marked departure of the trunk a. gastrica dextra with a branch to the duodenal pseudodiverticul. A. gastrica dextra is tied and crossed. The duodenal pseudodiverticul is invaginated into the lumen of the duodenal bulb by serous-muscular sutures. For 19 months postoperative monitoring relapse of bleeding was not detected.

Key words: chronic reccurent gastrointestinal bleeding; duodenal pseudodiverticulum, pseudoaneurysm of proper hepatic artery.

Л. С. БЕЛЯНСКИЙ, Н. С. СЛУШИНСКИЙ, А. Д. КАЛЬЧЕНКО

Национальный медицинский университет имени А. А. Богомольца

\section{РЕЦИДИВИРУЮЩЕЕ ХРОНИЧЕСКОЕ ЖЕЛУДОЧНО-КИШЕЧНОЕ КРОВОТЕЧЕНИЕ, ОБУС.ЛОВЛЕННОЕ ПСЕВДОАНЕВРИЗМОЙ СОБСТВЕННОЙ ПЕЧЕНОЧНОЙ АРТЕРИИ И ПСЕВДОДИВЕРТИКУЛОМ ЛУКОВИЦЫ ДВЕНАДЦАТИПЕРСТНОЙ КИШКИ}

\begin{abstract}
В статье представлен клинический случай хирургического лечения псевдоаневризмы собственной печеночной артерии, псевдодивертикула двенадцатиперстной кишки с рецидивирующим хроническим кровотечением. Больному с рецидивирующим хроническим кровотечением в течение 2 лет выполнено КТ ОБП с внутривенным контрастированием, 3D моделирование ветвей truncus coeliacus, по результатам которого у пациента выявлено KT-признаки аневризмы а.hераtica propria. Принято решение о проведении верхней срединной лапаротомии, интраоперационно обнаружены аневризма а.hepatica propria, от верхушки псевдоаневризмы отмечено отхождение ствола а. gastrica dextra с веткой к псевдодивертикулу двенадцатиперстной кишки. A. gastrica dextra перевязана и пересечена. Псевдодивертикул двенадцатиперстной кишки инвагинирован в просвет луковицы двенадцатиперстной кишки серозно-мышечными швами. В течение 19 месяцев послеоперационного наблюдения рецидива кровотечения не обнаружено.
\end{abstract}

Ключевые слова: хроническое рецидивирующее желудочно-кишечное кровотечение; псевдодивертикул двенадцатиперстной кишки; псевдоаневризма а.hepatica propria. 